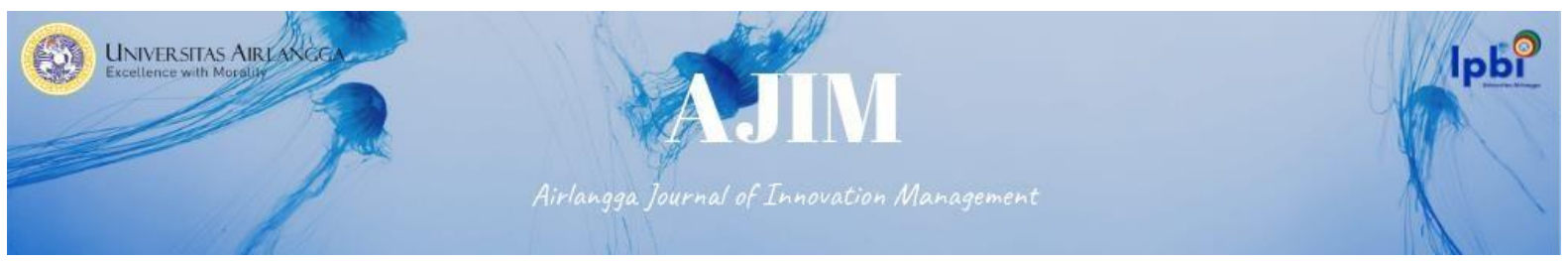

Vol. 2 No.1 Juni 2021

e-ISSN: 2722-5062

DOI : 10.20473/ajim.vvii.26567

\title{
SUCCESSION PLANNING IN MICRO AND SMALL FAMILY BUSINESS (CASE: MICRO AND SMALL FAMILY BUSINESS IN EAST JAKARTA)
}

\author{
Sakti Hendra Pramudya ${ }^{3}$ \\ University of Pécs, BINUS University \\ Corresponding email: sakti.pramudya@binus.ac.id
}

\begin{abstract}
Family business studies are gaining a foothold in Indonesia as more studies on Indonesian family business have been emerging in numerous scientific journals. The family business organization is the most commonly found type of business all over the world. Nonetheless, the family business survival rate is considered low. The low survival rate of the family business, according to several studies, is also related to the issue of management succession, a delicate situation that they need to face. This study will focus on identifying the level of the importance of succession planning for family business owners, especially those belonging to the micro and small business category. The study involved one-hundred micro and small family business owners in East Jakarta as respondents of the survey. This study would be focused on identifying the ground rules that are created by incumbents during succession planning. The findings will be presented in the pie charts that reflect the results of the descriptive statistics of the study. This study has revealed that the majority of the respondents in the sample don't have an appropriate plan of succession. Nevertheless, they believe that succession is an important issue but this issue is not necessarily to be addressed at the moment. The result also exhibits that majority of respondents favoring their child as future successor. Lastly, the homosocial reproduction phenomenon also could be identified from the survey as the majority of respondents define a good successor as someone who has a vision that in line with the predecessor's vision.
\end{abstract}

Keywords: Succession, Planning, Family, Business, Jakarta

\section{Introduction}

Previous research has demonstrated that family businesses assume a noteworthy part in boosting GDP providing employment opportunity as experienced by Indonesia (Ghee, Ibrahim \& Halim, 2015). Family businesses have contributed to 25\% of Indonesian GDP and almost 95\% of Indonesian businesses are managed by families (PricewaterhouseCoopers, 2014). Performance of large Indonesian family business could be considered as moderately strong. The presence of family-owned businesses in LQ45 (top performing companies in stock market) is significantly high as depicted in Table 1. 


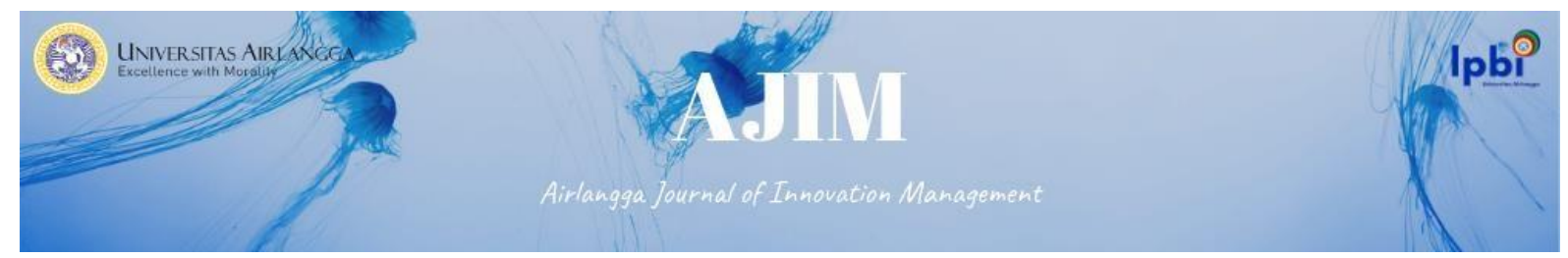

Table 1. Indonesian family businesses which are listed in LQ45 (top performing companies in stocks market) as of February 2017

\begin{tabular}{|l|c|l|}
\hline \multicolumn{1}{|c|}{ Name } & Business Sector & \multicolumn{1}{c|}{ Owner } \\
\hline Astra Agro Lestari Tbk & Plantation & Soeryadjaja family \\
\hline AKR Corporindo Tbk & Logistics & Adikoesoemo family \\
\hline Astra International Tbk & Automotive & Soeryadjaja family \\
\hline Alam Sutra Realty Tbk & Property & Tirtohadiguno family \\
\hline PT Bumi Serpong Damai Tbk & Property & Widjaja family \\
\hline Charoen Pokphand Indonesia Tbk & Poultry & Chearavanont family \\
\hline Gudang Garam Tbk & Cigarettes & Wonowidjojo family \\
\hline Indofood CBP Sukses Makmur Tbk & Food & Salim family \\
\hline Kalbe Farma Tbk & Medicine & Setiawan family \\
\hline Lippo Karawaci Tbk & Property & Riady family \\
\hline Matahari Department Store Tbk & Dept. Store & Darmawan family \\
\hline Media Nusantara Citra Tbk & Televison & Tanoesoedibjo family \\
\hline Pakuwon Jati Tbk & Property & Tedja family \\
\hline Surya Citra Media Tbk & Television & Sariaatmadja family \\
\hline Summarecon Agung Tbk & Property & Nagaria family \\
\hline PT Sri Rejeki Isman Tbk & Textiles & Lukminto family \\
\hline PT Sawit Sumbermas Sarana Tbk. & Plantation & Haji Rasjid family \\
\hline Source: Indonesa Stock Exhange & &
\end{tabular}

Source: Indonesia Stock Exchange (2017)

The number of family business in level of micro and small enterprise is more staggering. According to Statistical Bureau of Indonesia and Central Bank of Indonesia, a microenterprise is defined as an enterprise which owned by a family and employs less than 5 people including unpaid family members. On the other hand, small enterprise employs 5 to 19 people and most of them also employ family members as employees (LPPI, 2015). Hence, almost all micro and small enterprises in Indonesia could be defined as a family business. As can be seen in Figure 1, the number of micro and small enterprise in Indonesia has been significantly increased from time to time.

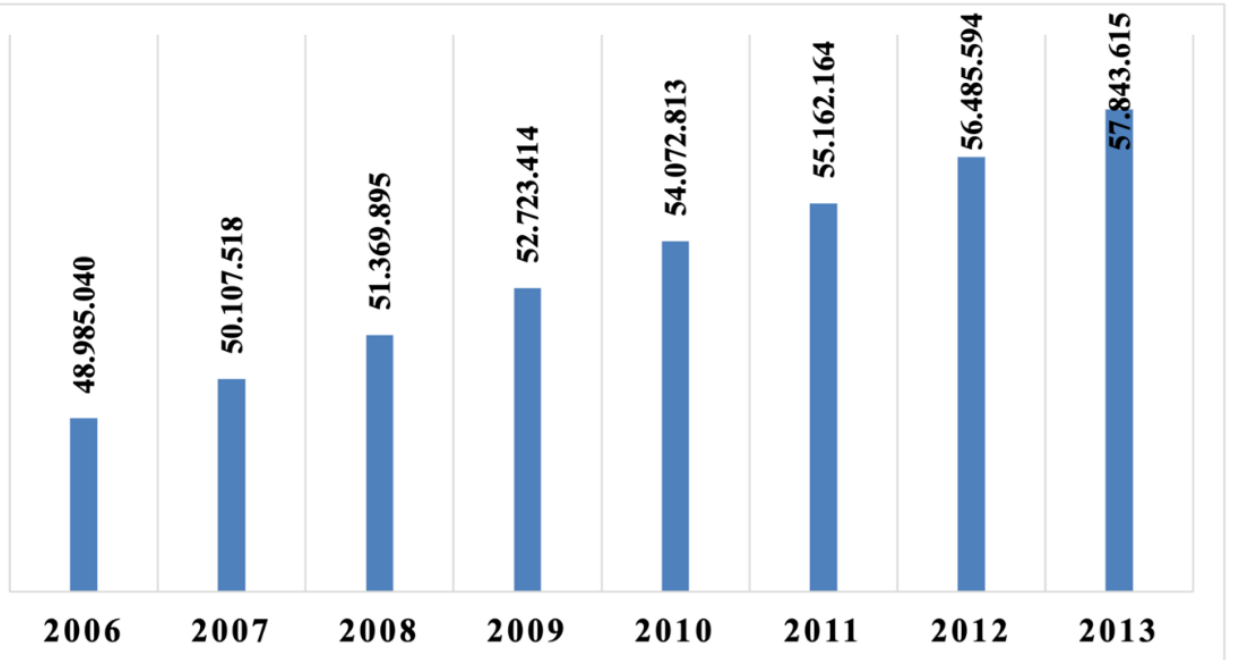

Figure 1. The number of micro and small enterprise in Indonesia (2006-2013) Source: Ministry of Cooperative and Small Medium Enterprise (2013) 


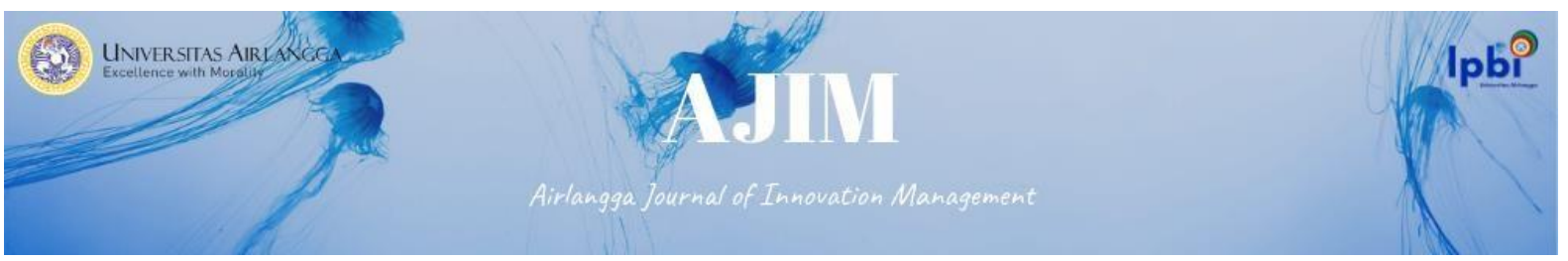

Besides an increase in numbers, micro and small enterprise also share largest proportion of business scale in Indonesia (approximately $98 \%$ of all business in Indonesia). Indonesian micro and small enterprise also being praised for their economic resilience during the crises, thus these enterprises could serve as a buffer for stability of financial economy system (Shinozaki, 2012). Despite their large number and resilience, Indonesian family business also known for its low survivability. Most of Indonesian family business does not manage to survive third generation due to lack of succession planning, especially on issue of management succession (Tirdasari \& Dhewanto, 2012; Tjiptono, 2013; Wahjono, 2009). Succession is a crucial part of family business development process, in which previous generation will hand over leadership torch to new generation. However, process itself is complicated and in some cases, a failed succession process may hamper firm performance. Therefore, a wellprepared succession plan needs to be formulated to avoid aforementioned situation. Nevertheless, further investigation needs to be done to identify readiness of Indonesian micro and small enterprise in facing succession, especially, in context of non-service industry. Number of non-service family businesses in Indonesia is large the available literature which discusses this industry context is limited (Karunia \& Mustamu, 2015; Sudibyo, 2014; Tjiang \& Mustamu, 2014). The problem would lead to main research question in this study; Do the Indonesian non-service micro and small family business already possessing plan for succession?

In order to answer previously mentioned question, a comprehensive analysis need to be done. This study would use survey research method to identify succession plan among micro and small family business goods manufacturer in Pulogadung, East Jakarta. Pulogadung is selected due to location is an integrated micro, small, and medium enterprise industrial area in which numerous micro and small family business are conducting their business here. The industrial area itself is managed and supervised by Provincial Government of Jakarta. There are approximately 600 SMEs which being managed by Provincial Government, with two-thirds of them is categorized as micro and small businesses. From 400 registered micro and small businesses, it is recorded those 320 businesses are managed by family business. From those 320 businesses, 100 businesses are selected as respondent of study. The data would be represented by using descriptive statistics method to provide a description of importance of succession planning for micro and small family businesses. The paper also includes literature review as theoretical foundation, research methodology, findings, and conclusion.

\section{Literature Review}

Succession is a process of transferring management and control which involves two generations or more. Family business capacities to fuel monetary advancement and development have always been anticipated when owners are credited with nurturing cross-generational entrepreneurial talent, a sense of loyalty to business success, long-term strategic commitment and corporate independence (Ghee, Ibrahim \& Halim, 2015; Poutziouris, 2001; Tatoglu, Kula \& Glaister, 2008). Succession processes in the family business could be considered as an HR practice. From HR point of view, every organization requires particular talent to assume the position in leading their organization and this particular talent would not be in the organization forever; thus, succession planning and management is needed to ensure the continuation of organization's effective performance (LeCounte, Prieto, \& Phipps, 2017; Rothwell, 2001). Stadler (2011) describes the main approaches which are used by companies to manage succession from the talent origin perspective. The first approach is short-term planning which usually prioritizes external talent to fill the position due to a sudden change in the organization. The second approach is appropriate long-term planning or managing talent which focuses on nurturing internal 


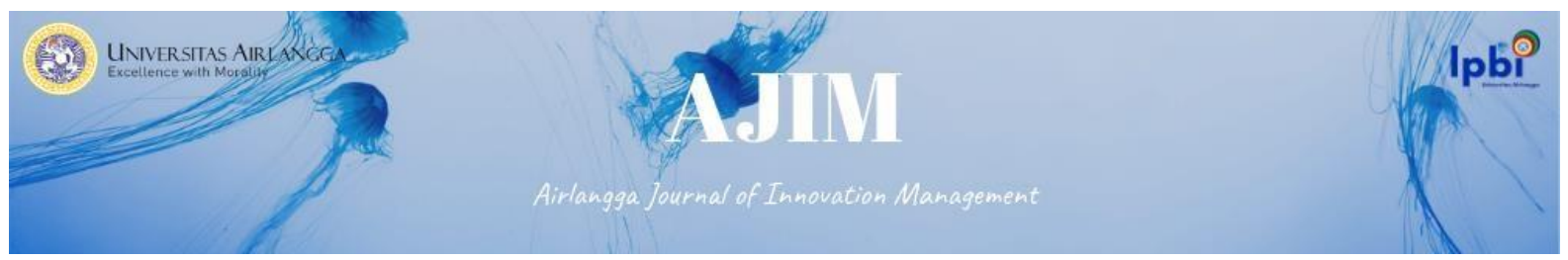

talent and the last approach is called a combination approach which promoting talent from within and outside the organization. In the context of family business, the succession is a quite complicated issue due to the intertwining of ownership and management (Luan, Chen, Huang, \& Wang, 2017). Thus the majority of family business successor would be selected from the members of the family due to incumbent's desire to keep the business in the family hands (Sharma, Chrisman, \& Chua, 2003).

Le Breton-Miller, Miller, and Steier (2004) have proposed a widely accepted integrated framework of family business succession. In order to achieve a successful succession process, a family business shall follow four consecutive steps. The first, and the most important, step in the succession process is ground rules. During this stage, the incumbent shall shares vision for the future to establish succession planning which includes creating selection criteria, providing the list of candidates, setting rules for choice, identifying potential successor(s), etc. The second step of this process is nurturing or development of successor(s). The nurturing stage is essential to identify potential successor as the incumbent would interact personally with successor via training program and apprenticeship. After nurturing the potential successor(s), the incumbent shall decide and select the successor(s). During this stage, incumbent requires designing a legitimate process of final selection criteria to select a person who fits with the firm. The last stage of the succession process involves two separate but closely associated action which is hand-off or transition process and transfer of capital. In this stage, the incumbent shall phase out and the selected successor shall phase in. This process still requires supervision from the incumbent to bridge the management interim and setting performance criteria for a successor. On the other hand, the transfer of capital to the new management shall begin to ensure business continuity. In this process, the partition of shares commonly found to avoid conflict between family members.

The ground rules of succession are the most important process of succession. In order to set the ground rules for succession, an appropriate successor selection planning need to be done. As mentioned by earlier Sharma et al. (2003) the likelihood of selecting family member as a successor is greater than selecting non-family member. Besides that, from the HR point of view, the 'homosocial reproduction' most likely exist during this stage (Garcia-Alvarez, Lopez-Sintas, \& Gonzalvo, 2002). Homosocial reproduction is a problem in succession planning due to the incumbent would force the successor to replicate predecessor image and business behavior (García-Álvarez \& López-Sintas, 2008). Nurturing successor based on the incumbent's image could jeopardize the succession process due to it may result in organizational politics and favoritism behavior toward one of the successors who successfully imitating the image of the incumbent (Hammet, 2008). The phenomenon is almost happening in every family business in the world including in Southeast Asia (Ting, 2020).

Besides that, previous research that has been done in multiple countries demonstrated that succession must be planned in advance in order to achieve a successful transition (Gilding, Gregory, \& Cosson, 2015; Lussier \& Sonfield, 2012). Nevertheless, there are several studies which demonstrate that the majority of family business are not eager to plan their succession process yet. Bruce and Picard (2006) emphasize that the majority of Canadian family business does not have a succession plan. The similar finding also found in the context of Argentinian family business. Kertesz and Atalaya (1999) research demonstrated that around $70 \%$ of founders of Argentinian family firms resisted preparing for succession that is already happening from generation to generation (Barbero \& Lluch, 2016).

In the context of Indonesian family-owned micro, small, and medium enterprise, only scant attention is given to the succession planning analysis especially in the context of non-service industry (PricewaterhouseCoopers, 2014), however, the available literature which discusses this industry context is limited (Karunia \& Mustamu, 2015; Sudibyo, 2014; Tjiang \& Mustamu, 2014). Rachmania, 


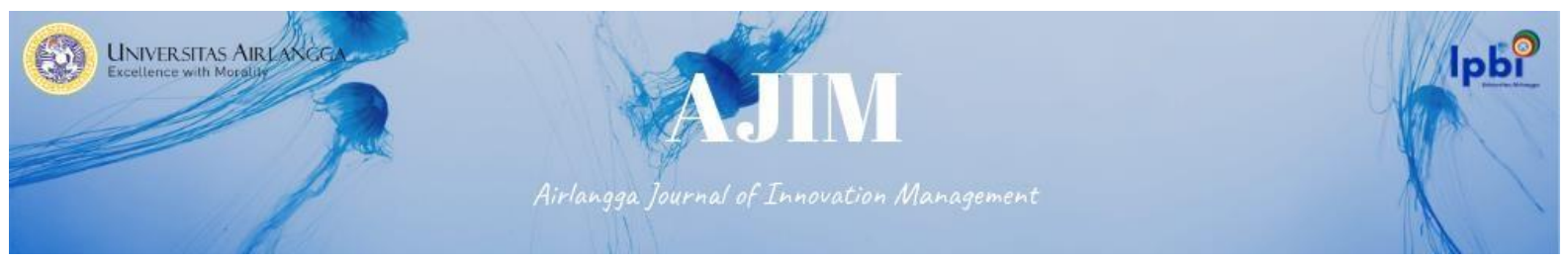

Rakhmaniar, and Setyaningsih (2012) have conducted a well-analyzed research which has a similar point of view with the study in which they reveal that the majority of Indonesian SME are originating from a family business. Their research has proven that the level of participation of family members in Indonesian SME is very high due to the business owners are more confident if assisted by family members. In the future, the business owners may choose their family members as their successor due to their familiarity with the business process and also more trustworthy than non-family employees. Based on aforementioned findings, it can be concluded that Indonesian family-owned SME, especially in the context of non-service industry is an under-researched topic and the available succession planning literature do not investigate the succession planning issues deeply; thus, further analysis is needed to be done to obtain distinct evidence about succession planning process which undertakes by Indonesian family-owned micro and small enterprises.

\section{Methods}

The study is quantitative in nature and utilizes survey research method. In order to obtain satisfactory survey result, a comprehensive questionnaire needs to be developed. Questionnaire is designed to obtain essential information about succession planning of a family business. As depicted in Table 2, questionnaire comprises of three section. First section comprises personal information of respondents which include gender, age, educational background, and type of business. Second part of questionnaire comprised of business characteristics of respondents namely type of business, number of employees, and age of business. Last section of questionnaire comprises of a series of multiple-choice questions which consist of close-ended and open-ended question to identify respondent's succession planning and readiness based on most important step of family business succession which is groundrule (general plan for succession and appropriate person to succeed the business).

Table 2. Questionnaire Sections and Its Indicators

\begin{tabular}{|c|c|c|}
\hline Sections & Indicators & References \\
\hline Personal Profile & Gender, Age, Educational Background, and Type of Business & Sharma, et al., 2003 \\
\hline $\begin{array}{l}\text { Business } \\
\text { Characteristics }\end{array}$ & $\begin{array}{l}\text { Type of Ownership, Number of Employees, and Age of } \\
\text { Business }\end{array}$ & Sharma, et al., 2003 \\
\hline $\begin{array}{l}\text { Succession } \\
\text { Readiness }\end{array}$ & $\begin{array}{l}\text { 1. Have you done your succession planning? } \\
\text { 2. Is succession planning an important thing to do? } \\
\text { 3. Is succession planning an important thing to do right now? } \\
\text { Please explain } \\
\text { 5. Who will be the appropriate successor of your business? } \\
\text { according to you? }\end{array}$ & $\begin{array}{l}\text { Garcia-Alvarez et } \\
\text { al., 2002, Le Breton- } \\
\text { Miller et al., 2004, } \\
\text { Sharma, et al., } 2003\end{array}$ \\
\hline
\end{tabular}

Source: author's evaluation based on conducted research.

The questionnaires were distributed to selected 100 family business owners which registered in Pulogadung Small and Medium Enterprises Development Management and Residential Area Management Unit in East Jakarta. There are approximately 600 SMEs which being managed by residential area management, with two-thirds of them is categorized as micro and small businesses. From the 400 registered micro and small businesses, it is recorded that 320 businesses are family owned. From those 320 businesses, 100 businesses are selected as the respondent of study due to their willingness to join research voluntarily. This research is using criteria of Indonesian Statistical Bureau and Central Bank of Indonesia to define business size of sample (LPPI, 2015). From 100 respondents 


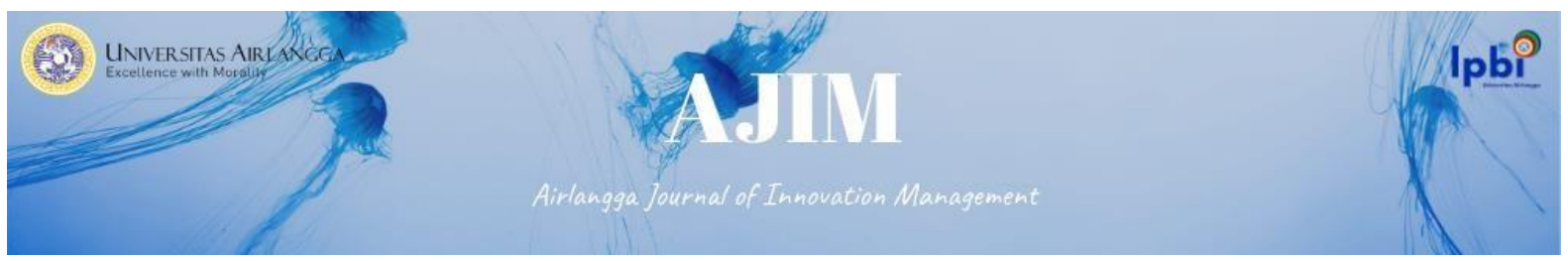

who participated in survey, 82 of them are categorized as microenterprise, due to they employ less than 10 people, and 18 businesses are categorized as small enterprise since they employ 10 to 20 employees. Pulogadung Small and Medium Enterprises Development Management and Residential Area Management Unit is selected as research location due to existence of numerous family-owned micro and small manufacturer which closely supervised by Provincial Government of Jakarta. Questionnaires were distributed to respondents on April 2nd, 2018 and all 100 questionnaires were returned completely. The data could be considered as representative due to response rate is consistent with other entrepreneurship surveys in Indonesia (Rachmania et al., 2012). Finally, analysis would use descriptive statistics method of frequency distribution analysis.

\section{Results and Discussion}

This section would discuss findings based on analysis of sample which includes descriptive statistics of respondent's personal profile, business characteristics, and succession readiness.

\subsection{Personal Profile}

As depicted in Table 3, majority of sample in this study is middle-aged male who completed high school and mostly engaged in tailor and fashion business. Characteristics of sample perfectly represent first-generation small business owners who build their very own business and currently has employed their family members as employee. Most of them are not possessing Bachelor degree, however, they possess hard skills and tenacity which more than enough to start their own business. Those hard skills would relevant for business who requires craftsmanship such as tailor and fashion as well as bag and shoe manufacturer.

Table 3. Sample's Personal Profile

\begin{tabular}{|c|c|c|}
\hline Profile & Frequency $(n=100)$ & Percentage (\%) \\
\hline $\begin{array}{cl}\text { Gender } & \\
\bullet & \text { Male } \\
\bullet & \text { Female }\end{array}$ & $\begin{array}{l}62 \\
38\end{array}$ & $\begin{array}{l}62 \\
38\end{array}$ \\
\hline $\begin{array}{l}\text { Age } \\
\text { - Less than } 25 \text { years old } \\
\text { - } 26-35 \text { years old } \\
\text { - } 36-45 \text { years old } \\
\text { - } 46-55 \text { years old } \\
\text { - } 65 \text { years old } \\
\text { more than } 65 \text { years old }\end{array}$ & $\begin{array}{c}0 \\
4 \\
12 \\
63 \\
13 \\
8\end{array}$ & $\begin{array}{c}0 \\
4 \\
12 \\
63 \\
13 \\
8\end{array}$ \\
\hline $\begin{array}{c}\text { Educational Background } \\
\text { - } \\
\text { Elementary School } \\
\text { - } \\
\text { - Senior High High School } \\
\text { - } \\
\text { - } \text { Bachloma } \\
\text { Master }\end{array}$ & $\begin{array}{c}0 \\
2 \\
40 \\
36 \\
22 \\
0\end{array}$ & $\begin{array}{c}0 \\
2 \\
40 \\
36 \\
22 \\
0\end{array}$ \\
\hline $\begin{array}{c}\text { Type of Business (according to sample) } \\
\text { - } \text { Manufacturing } \\
\text { - } \text { Tailor and Fashion } \\
\text { - Pood Services } \\
\text { - } \text { Pacard } \\
\text { - } \text { Shoes Production } \\
\text { Other Services }\end{array}$ & $\begin{array}{c}12 \\
32 \\
4 \\
3 \\
20 \\
18 \\
11\end{array}$ & $\begin{array}{c}12 \\
32 \\
4 \\
3 \\
20 \\
18 \\
11\end{array}$ \\
\hline
\end{tabular}

Source: author's evaluation based on conducted research. 


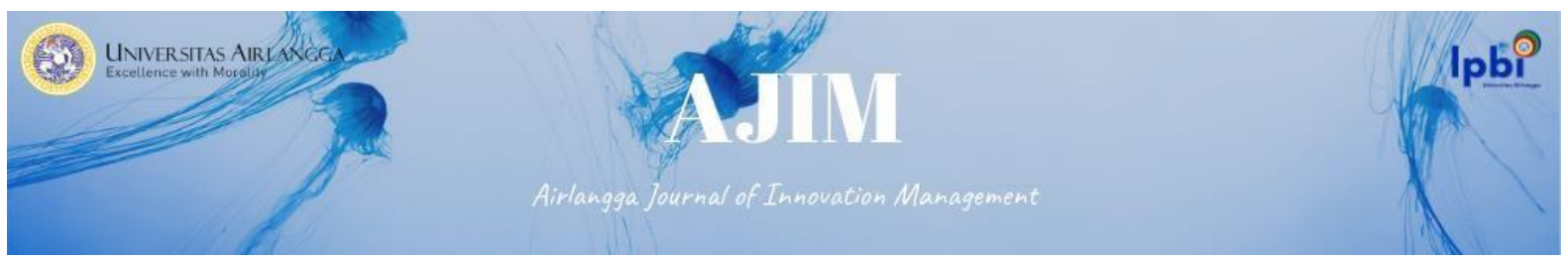

\subsection{Business Characteristics}

The majority of family business in sample are owned solely by one person who employs less than 10 employees and has already been operated less than 10 years as depicted in Table 4 . The finding reflects that majority of family business owner in sample would rather manage their business on their own rather than sharing ownership with partner. Besides that, majority of sample, in turn, has been operated less than 10 years. Due to firm is relatively still 'young', number of employees which hired by them also relatively few as a result of firm efficiency.

Table 4. Sample's Business Characteristics

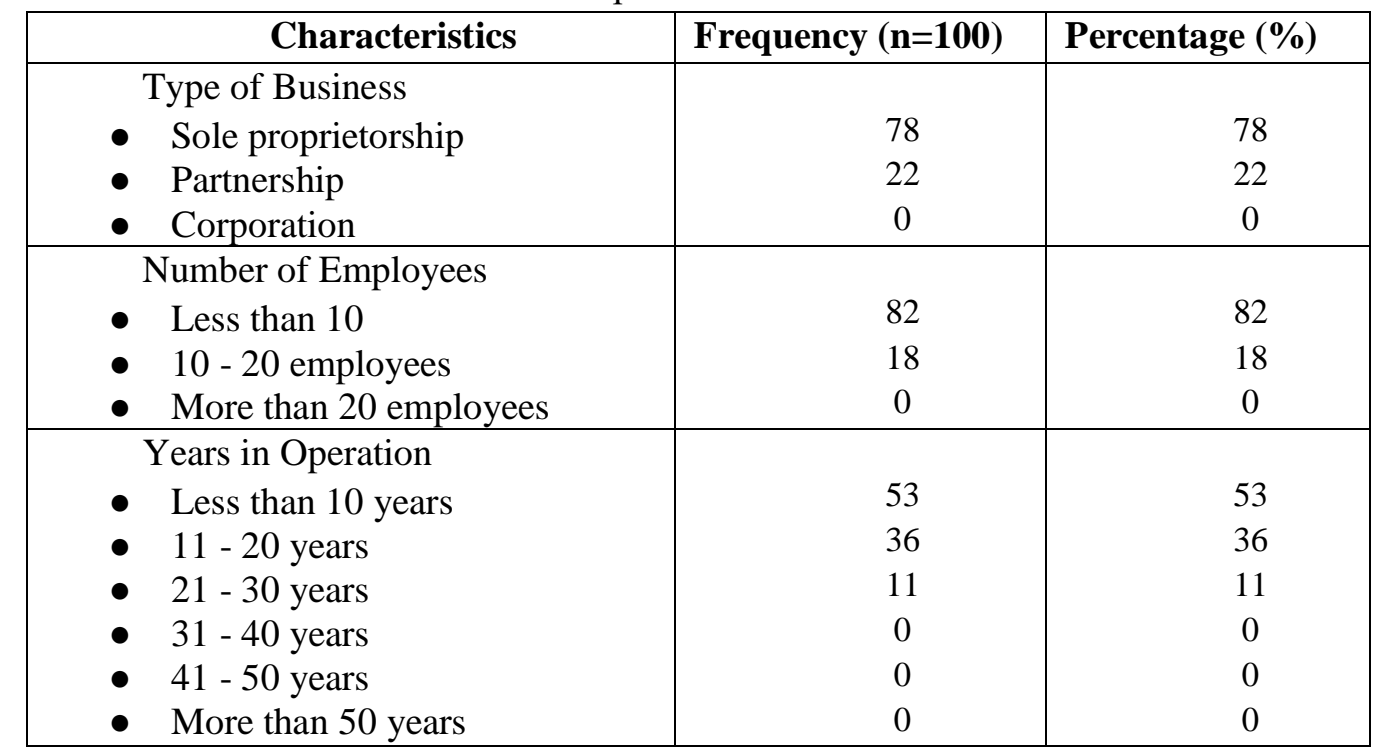

Source: author's evaluation based on conducted research.

\subsection{The Ground Rules of Succession Planning}

There are five indicators which are used to identify succession planning ground rules in this study. First indicator would identify possession of succession planning. Respondent was asked whether they have done succession planning in their business or not. Surprisingly, almost all of respondents responded that they have not formulated any succession plan to date (as depicted in Figure 2).

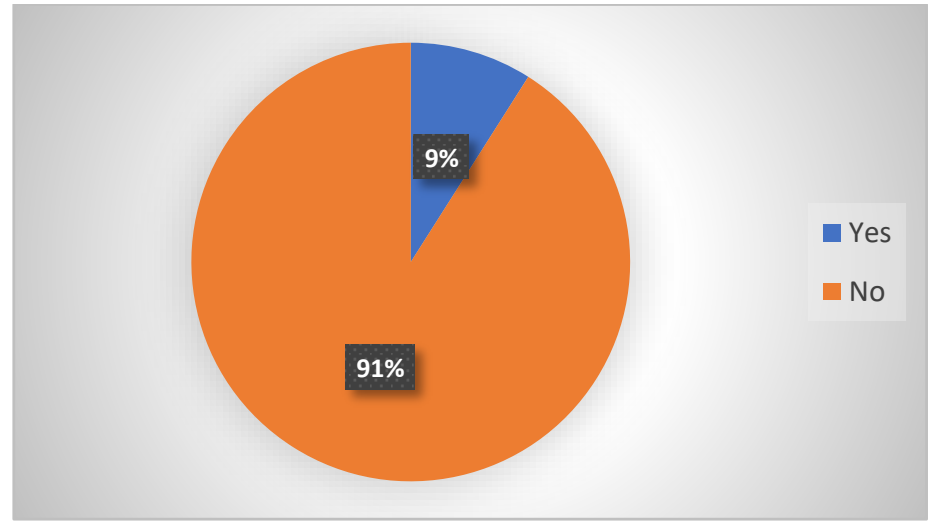

Figure 2. Have you done your succession plan?

Source: author's evaluation based on conducted research. 


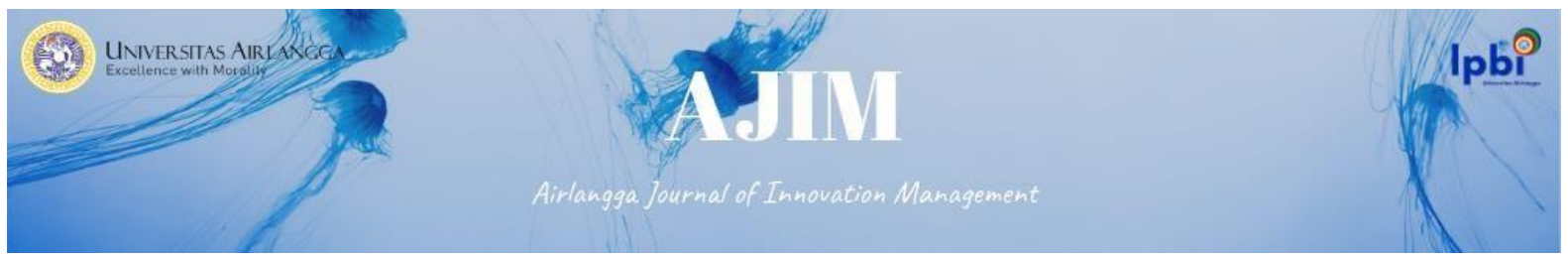

The result is in line with Bruce and Picard (2006) as well as Kertesz and Atalaya (1999) findings in which majority of family-owned micro, small, and medium enterprise in Indonesia do not have an appropriate succession plan. This could be a warning for family businesses in Indonesia since lack of appropriate time to plan and conduct succession is a significant contributor to failed succession process which may hamper firm's performance. A fail succession process would create larger detrimental effect on micro and small enterprise due to any internal issues in organization may significantly impact their business process. After identifying possession of succession planning, second indicator of succession readiness is importance of succession planning in business owners mind. Surprisingly, even though to date they still have not formulated any succession plan, they are aware that succession planning is an important issue (as depicted in Figure 3).

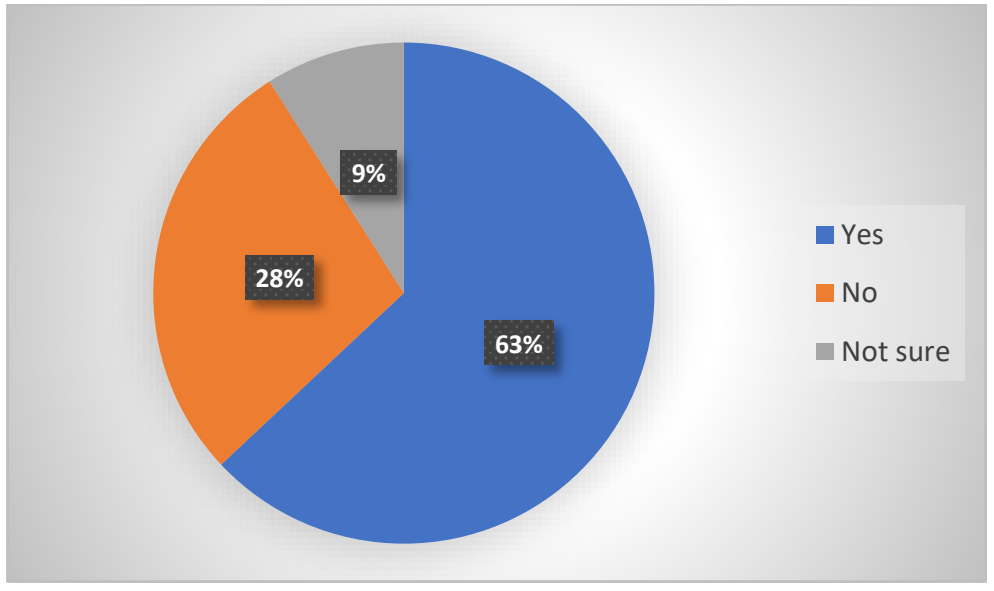

Figure 3. Is succession planning important thing to do?

Source: author's evaluation based on conducted research.

Nonetheless, even though respondents are aware of importance of succession planning, majority of sample perceive that succession planning is not necessarily to be done right now.

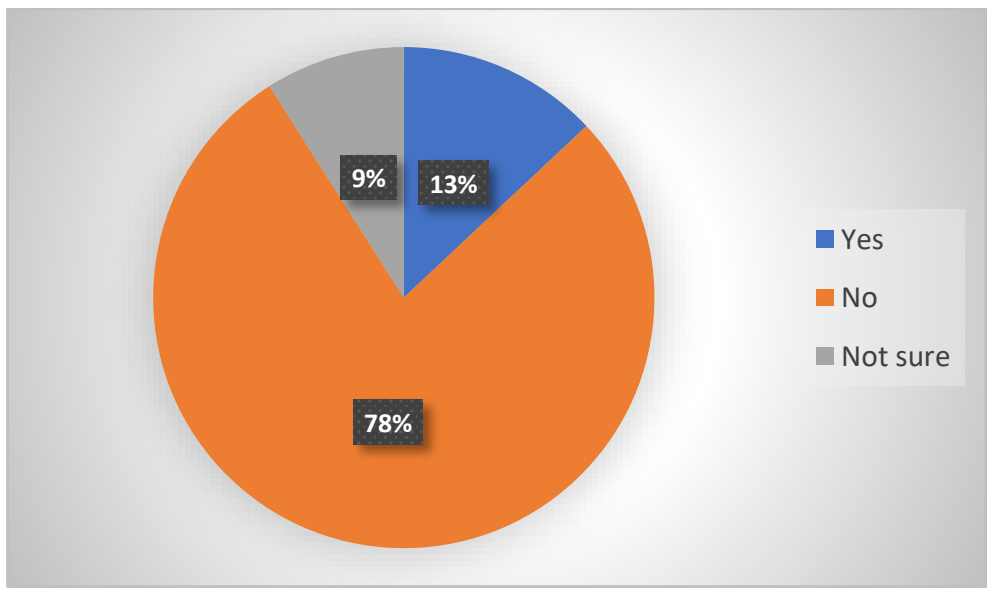

Figure 4. Is succession planning important thing to do right now?

Source: author's evaluation based on conducted research. 


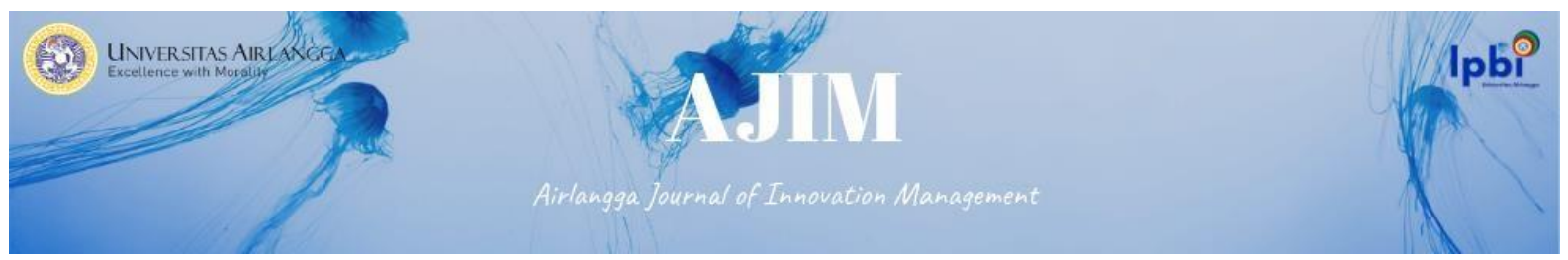

As depicted in Figure 4, urgency of succession planning is not top priority of business owners in sample. This paradox in turn related to reason behind their answers. After responding to urgency of succession planning question, respondents are asked to state their reason why they are answering 'yes', 'no', or 'not sure'. The reason why majority of respondents perceive that succession planning is not an urgent call, in turn, is as a result of strong sense of belonging to business followed by absence of successor who meets incumbent criteria (as depicted in Figure 5).

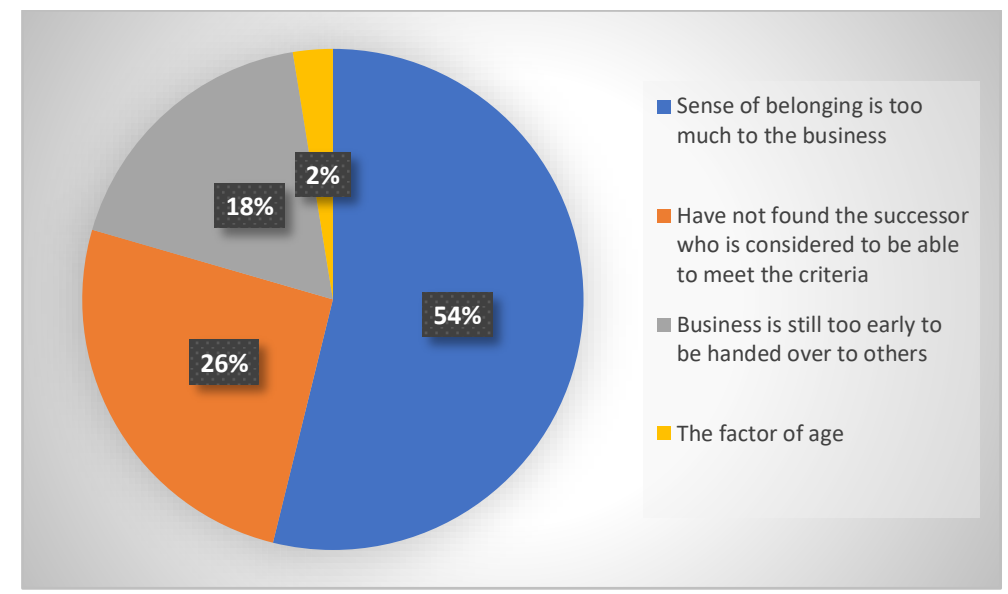

Figure 5. The reason why respondents feel that succession planning is not an urgent call. Source: author's evaluation based on conducted research

Losing control of business which has been built by owners for many years in some cases is difficult for them due to they may afraid of losing their identity and status in society (Filser, Kraus, \& Märk, 2013; Potts, Schoen, Engel-Loeb, \& Hulme, 2001). It is interesting that even succession planning, which is important according to them, response of majority respondent exhibit particular traits as if succession process will be conducted very soon and process itself would rule them out from their business. Hence, some irrelevant responses may emerge such as reason why succession planning is not an urgent call is due to too much sense of belonging to business. The response reflects that reason why business owners do not formulate plan yet is due to they do not want business to be lead and owned by someone else in near future. Even though their response seems unreasonable, respondents exhibit a strong sense of love toward business.

The next reason why respondents feel that succession planning is not an urgent call is related to absence of successor who meets owner's criteria. Nurturing an appropriate successor is not an easy task. The incumbent, as older generation, need to collaborate with successors who come from younger generation and it is quite difficult due to generation gap (Barnett and Davis, 2008). Miller, Steier, and Le Breton-Miller (2003) also mentioned that an incumbent may exhibit negative traits toward potential successor such as a tendency to mistrust, controlling every aspect of business, and even to be negatively aggressive. This behavior, in certain cases, is root cause why incumbent still have not found an 'appropriate' successor.

In contrast, reason why some of respondents feel that succession planning is an urgent call that needs to be done immediately is due to age factor as depicted in Figure 6. Majority of respondents who perceive that succession planning is needed to be done as soon as possible are business owners who already passing their productive age and considering retirement. They are senior business owners who already approaching retirement age who need a successor to replace their managerial position. The 


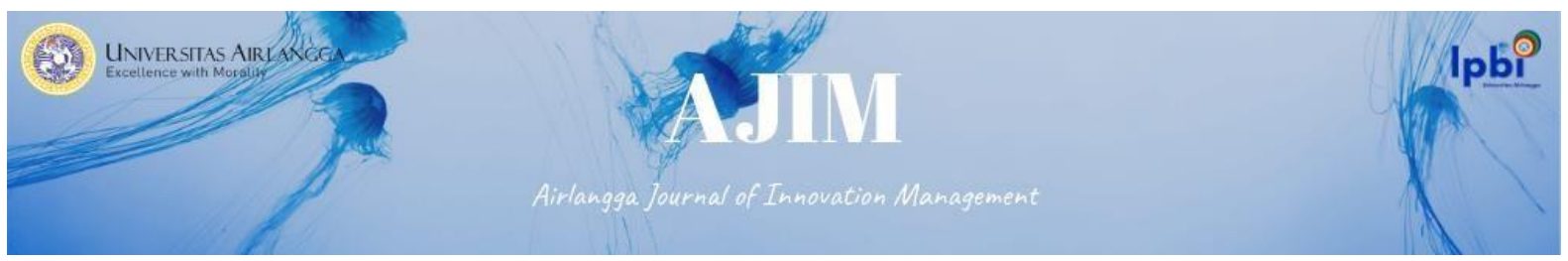

finding is relevant with Marshall, Sorenson, Brigham, Wieling, Reifman, and Wampler (2006) which state that increase in family business owner age is stimulus of succession planning for purpose of their retirement.

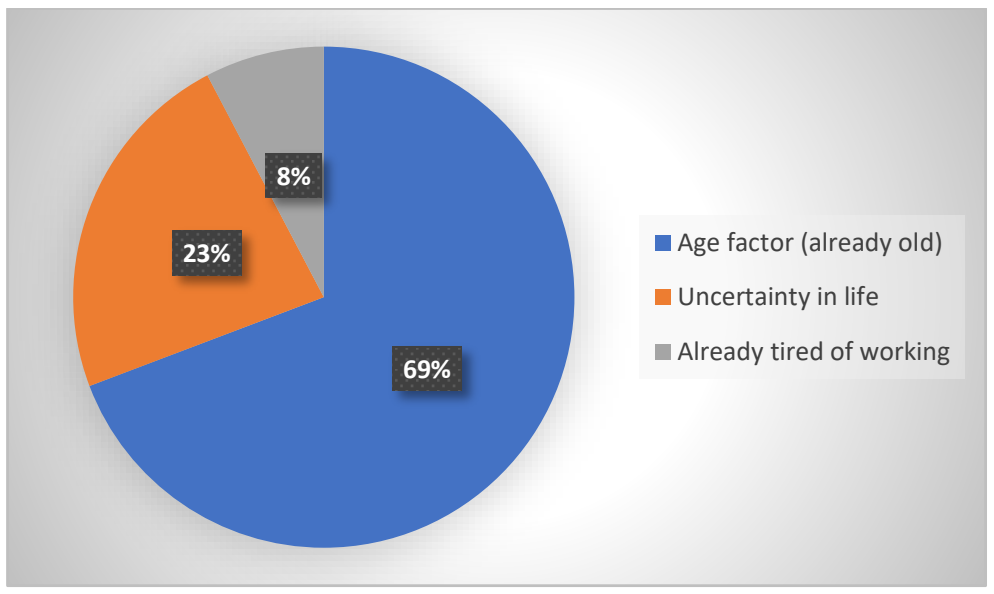

Figure 6. The reason why respondent respondents feel that succession planning is an urgent call. Source: author's evaluation based on conducted research

The next indicator of a solid succession ground rule is related to successor criteria in term of who will be appropriate successor. Even though question is an open-ended question, surprisingly, majority of respondents mention that family members as their successor and there is no respondent who mentions 'outsider' as the appropriate successor. The finding is in line with Sharma et al. (2003) in which family business tend to choose family members as their successor to preserve family interests thus they do not give an opportunity from someone 'outside' their family as he candidate to succeed their business. The respondent responses could be seen in Figure 7.

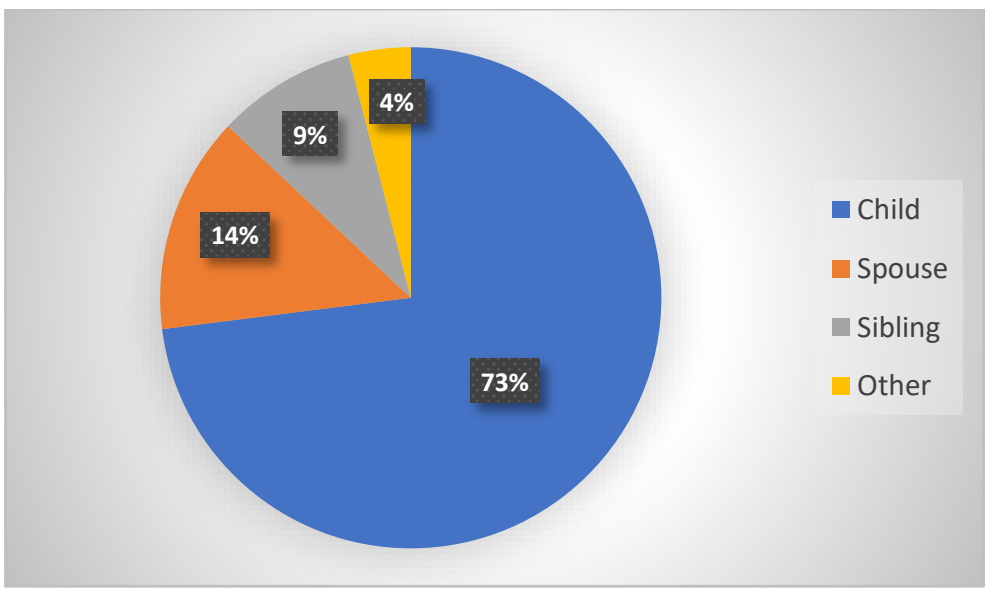

Figure 7. Who will be the appropriate successor of your business?

Source: author's evaluation based on conducted research

Finally, last analysis in this study is related to most important criterion of a good successor. With regards to the aforementioned question, another surprising finding emerges the survey as can be seen in Figure 8. According to respondent, most important criterion of a good successor is someone 


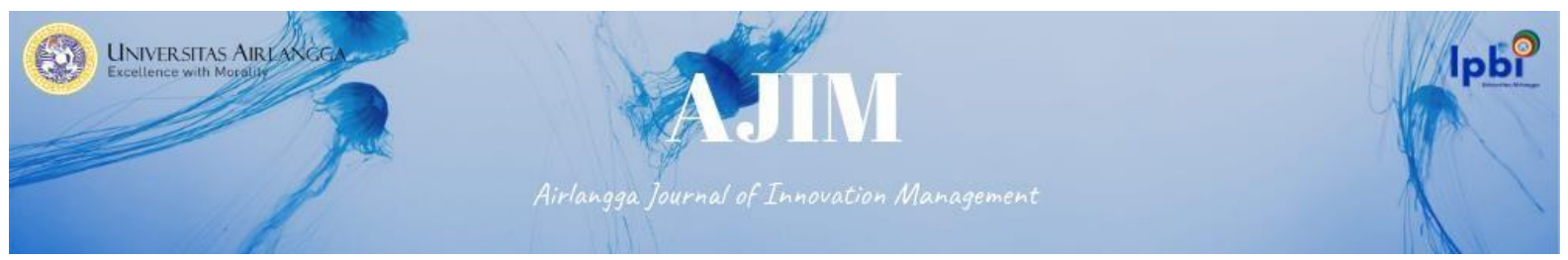

who has similar vision like predecessor. Hence, existence of homosocial reproduction phenomenon is strong in this study. It is interesting that homosocial reproduction phenomenon, in fact, does not only occur in large and well-established family business setting but also in the context of a micro and small enterprise. The homosocial reproduction mindset would hazardous both for succession process and also for management of business. This mindset would hamper a fair succession process which should be based on talent assessment in managing business. Moreover, those mindset would confine successor to be more creative in developing their business due to incumbent would be favoring a candidate with same vision in managing business.

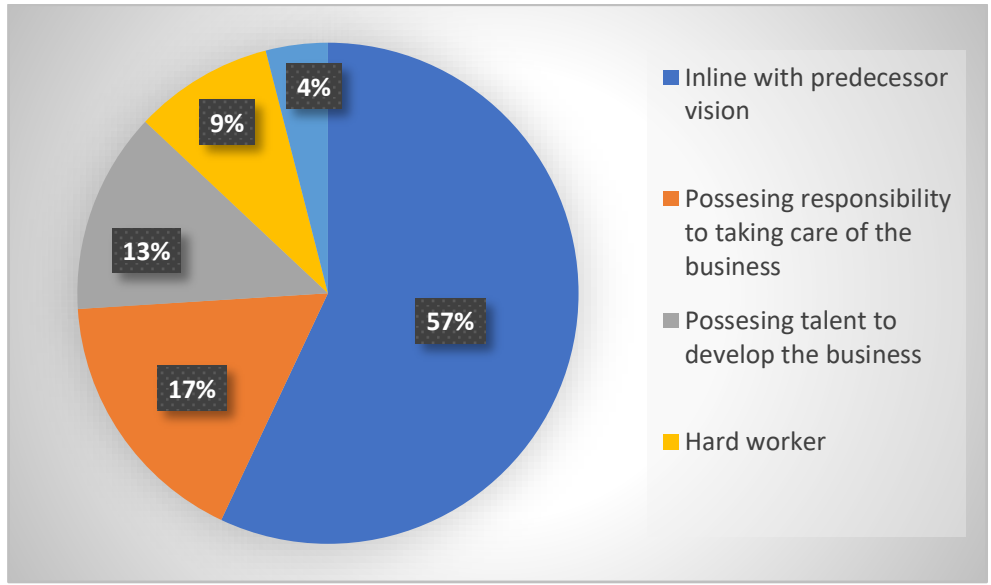

Figure 8. What is the most important criterion of a good successor according to you?

Source: author's evaluation based on conducted research

\section{Conclusion}

This study has revealed that majority of Indonesian micro and small family owned manufacturer in this sample do not have an appropriate plan of succession. Even though they do not have an appropriate plan for succession they do perceive that succession planning is an essential task to do. However, they feel that process is not necessarily conducted at present. The reason why respondents feel that succession planning is not an urgent call is mostly related to strong attachment and belonging of owners to business as well as absence of appropriate successor. The reason why business owners do not formulate plan yet is due to they do not want business to be lead and owned by someone else. Even though their response seems unreasonable, respondents exhibit a strong sense of love toward business. Nonetheless, there are several respondents who feel that succession planning is an urgent call due to their age is approaching retirement age. This findings should be a warning for Indonesian family-owned micro and small enterprise due to succession process itself is not an easy task. Process would take time and involve collaboration between incumbent and successor.

This study also revealed that majority of sample is defining an appropriate successor should be one of their family members. It is interesting that in fact, sense of belonging to business for majority of respondent is so great thus they do not want to be succeeded by someone else from outside their family. Finally, it is revealed that homosocial reproduction phenomenon occurs in sample. As mentioned by Hammet (2008) incumbent desire to nurture a successor which mirror their self could jeopardize succession process. Moreover, if successor is selected based on traits similarity of incumbent, organization more likely become stagnant and do not innovate since mindset of business management 


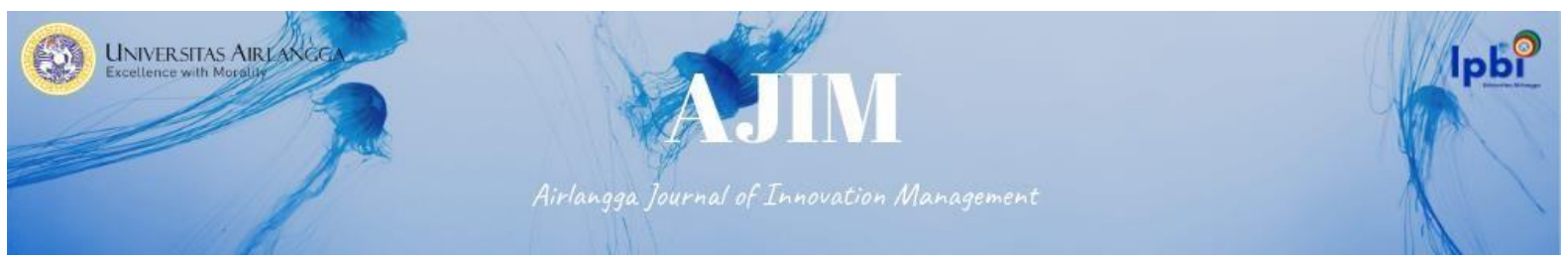

is based on predecessor's point of view which sometimes irrelevant in this fast-paced business environment.

Based on aforementioned findings, we suggest that a well-established ground rule of succession planning is needed to be formulated in advance especially with regard to selection criteria. However, selection criteria itself should be determined in a professional manner which reflects best talent acquisition spirit. It is imperative that homosocial reproduction mindset should not be exhibited, even it is reasonable for an incumbent to have an attachment toward the business. If a solid ground rule for succession has been successfully made, a smooth nurturing, selection, and hand-off process will be conducted smoothly.

\section{References}

Barbero, M. I., \& Lluch, A. (2016). Family capitalism in Argentina: Changes and continuity over the course of a century. In Evolution of family business. Edward Elgar Publishing.

Barnett, R., \& Davis, S. (2008). Creating Greater Success in Succession Planning. Advances in Developing Human Resources, 10(5), 721.

Bruce, D., \& Picard, D. (2006). Making Succession a Success : Perspectives from Canadian Small and Medium-Sized Enterprises. Journal of Small Business Management 44(2). 306-309.

Filser, M., Kraus, S., \& Märk, S. (2013). Psychological aspects of succession in family business management. Management Research Review.

Garcia-Alvarez, E., Lopez-Sintas, J., \& Gonzalvo, P.S. (2002). Socialization Patterns of Successors in First- to Second-Generation Family Businesses. Family Business Review, 15, 189-203.

García-Álvarez, E., \& López-Sintas, J. (2008). 13 Founder-successor's transition: a model of coherent value transmission paths. Handbook of research on family business, 237.

Ghee, W. Y., Ibrahim, M. D., \& Halim, H. A. (2015). Family Business Succession Planning: Unleashing The Key Factors of Business Performance. Asian Academy of Management Journal, 20(2), $103-126$.

Gilding, M., Gregory, S., \& Cosson, B. (2015). Motives and outcomes in family business succession planning. Entrepreneurship Theory and Practice, 39(2), 299-312.

Indonesia Stock Exchange. (2017). LQ45; February 2017. Jakarta.

Lussier, R. N., \& Sonfield, M. C. (2012). Family businesses' succession planning: a seven-country comparison. Journal of Small Business and Enterprise Development.

Hammett, P. (2008). The paradox of gifted leadership: developing the generation of leaders. Journal of Industrial and Commercial Training, 40(1), 3-9.

Kementerian Koperasi dan Usaha Kecil dan Menengah Republik Indonesia (2014), Data Usaha Mikro, Kecil, Menengah (UMKM) dan Usaha Besar (UB) Tahun 2012 - 2013, http://www.depkop.go.id/pdf viewer/?p=uploads/tx_rtgfiles/sandingan_data_umkm_20122013.pdf, accessed on 20 Februari 2018

Kertesz, R., Atalaya, C.I. (1999). Family Businesses in Argentina: Current Issues. Community, Work and Family, 2(1), 93- 103.

Le Breton-Miller, I., Miller, D., \& Steier, L. (2004). Toward an integrative model of effective FOB succession. Entrepreneurship Theory and Practice, 28, 305-328.

LeCounte, J. F., Prieto, L. C., \& Phipps, S. T. (2017). CEO succession planning and organizational performance: A human capital theory approach. Journal of Leadership, Accountability, and Ethics, 14(1), 46-57. 


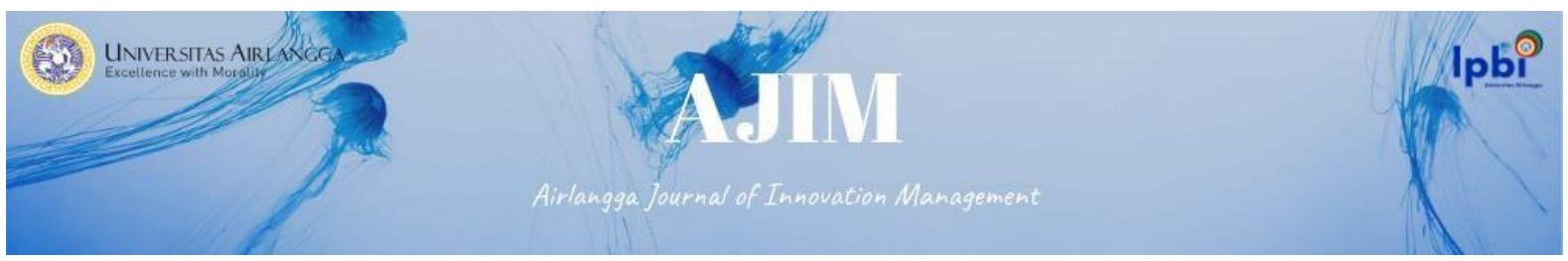

LPPI. (2015). Profil Bisnis Usaha Mikro, Kecil, dan Menengah (UMKM). Jakarta, Indonesia: Bank Indonesia.

Luan, C. J., Chen, Y. Y., Huang, H. Y., \& Wang, K. S. (2017). CEO succession decision in family businesses - A corporate governance perspective. Asia Pacific Management Review, 1-7.

Marshall, J. P., Sorenson, R., Brigham, K., Wieling, W., Reifman, A., Wampler, R. S. (2006). The Paradox for The Family Firm CEO: Owner Age Relationship to Succession-Related Processes and Plans. Journal of Business Venturing, 21, 348- 368.

Miller, D., Steier, L., \& Le Breton-Miller, I. (2003). Lost in time: Intergenerational succession, change, and failure in family business. Journal of business venturing, 18(4), 513-531.

Potts, T.L., Schoen, J.E., Engel-Loeb, M., \& Hulme, F.S. (2001). Effective Retirement for Family Business Owner-Managers: Perspectives of Financial Planners - Part 2. Journal of Financial Planning, 14(7), 86-96.

Poutziouris, P. (2001). The (re)-emergence of Growth vis-a -vis Control Dilemma in a Family Business Growth Star: The Case of The UK Taramasalata Kings. In P. Poutziouris, \& D. Pistrui (Eds.), Family Business Research in The Third Millennium: Building Bridges Between Theory and Practice (pp. 88-103). Boston, MA: The Family Firm Institute Publication.

PricewaterhouseCoopers. (2014). Survey Bisnis Keluarga 2014 di Indonesia. Jakarta:

Rachmania, I. N., Rakhmaniar, M., Setyaningsih, S. (2012): Influencing Factors of Entrepreneurial Development in Indonesia. In: C. B. Nawanglupi, G. Pawitan \& C. Sitompul (Eds.), Procedia Economics and Finance: Proceeding of the International Conference on Small and Medium Enterprises Development with a Theme "Innovation and Sustainability in SME Development" (ICSMED 2012) (pp. 234-243). Amsterdam: Elsevier

Rothwell, W. (2001). Effective Succession Planning: Ensuring Leadership Continuity and Building Talent from Within. 2nd ed. New York: Amacom.

Karunia, H. \& Mustamu, S. H. (2015). Analisis Perencanaan Suksesi Pada Perusahaan Keluarga Industri Baja. AGORA, 3(1), 215-221.

Sharma, P., Chirsman, J. J., Chua, J. H. (2003). Succession Planning as Planned Behavior: Some Empirical Results. Family Business Review, 16(1), 1-16.

Shinozaki, S. (2012). A New Regime of SME Finance in Emerging Asia: Empowering GrowthOriented SMEs to Build Resilient National Economies. ADB Working Paper Series on Regional Economic Integration. No. 104 | December 2012. Asian Development Bank.

Stadler, K. (2011). Talent Reviews: The key to effective succession management. Business Strategy Series, 12(5), 264-271.

Sudibyo, Y. P. (2014). Tahapan, Faktor Pendukung, dan Faktor Penghambat Perencanaan Suksesi Kepemimpinan Generasi Ke-Tiga Pada Perusahaan Keluarga PT. Lubrical Suga Sejahtera di Pasuruan. AGORA, 2(2), 957-961.

Tatoglu, E., Kula, V., \& Glaister, K. W. (2008). Succession planning in family-owned businesses: evidence from Turkey. International Small Business Journal, 26, 155-180.

Ting, S. H. (2020). Modes of Value Transfer in Chinese Family Business in Malaysia. Asian Business Review, 10(1), 29-36.

Tirdasari, N. L., Dhewanto, W. (2012): Family Business Succession in Indonesia: A Study of Hospitality Industry. Procedia - Social and Behavioral Sciences. 9. pp. 69-74.

Tjiang, C. G. \& Mustamu, S. H. (2014). Studi Deskriptif Perencanaan Suksesi Kepemimpinan pada Perusahaan Keluarga di Bidang Konstruksi di Sidoarjo. AGORA, 2(2), 1369-1379. 


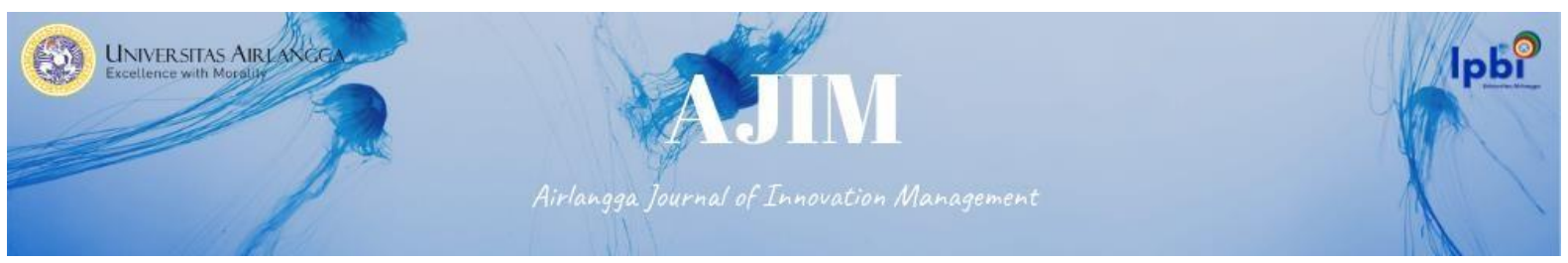

Tjiptono, F. (2013). Kelanggengan Entrepreneurship dalam Bentuk Bisnis Keluarga: Apa yang Telah dan Masih Perlu Diungkap. Jurnal Entrepreneur dan Entrepreneurship, 2(1), 1-12.

Wahjono, S. I. W. (2009). Suksesi Dalam Perusahaan Keluarga, Jurnal Balance, 3(1), 1-15. 